\title{
CFTR Is Involved in the Fine Tuning of Intracellular Redox Status
}

\section{Physiological Implications in Cystic Fibrosis}

\author{
Christophe Duranton, ${ }^{*}$ Isabelle Rubera, ${ }^{*}$ \\ Marc Cougnon, ${ }^{*}$ Nicolas Melis, ${ }^{*}$ \\ Abderrahman Chargui, ${ }^{\dagger}$ Baharia Mograbi, ${ }^{\dagger}$ and \\ Michel Tauc* \\ From the Faculties of Sciences LP2M CNRS-3472,* and Medicine \\ ERI 21, University of Nice-Sophia Antipolis, Nice, France
}

\begin{abstract}
Adaptation to hypoxia is an essential physiological response to decrease in tissue oxygenation. This process is primarily under the control of transcriptional activator hypoxia-inducible factor (HIF1). A better understanding of the intracellular HIF1 stabilization pathway would help in management of various diseases characterized by anemia. Among human pathologies, cystic fibrosis disease is characterized by a chronic anemia that is inadequately compensated by the classical erythroid response mediated by the HIF pathway. Because the kidney expresses CFTR and is a master organ involved in the adaptation to hypoxia, we used renal cells to explore the relationship between CFTR and the HIF1-mediated pathway. To monitor the adaptive response to hypoxia, we engineered a hypoxia-induced fluorescent reporter system to determine whether CFTR modulates hypoxia-induced HIF1 stabilization. We show that CFTR is a regulator of HIF stabilization by controlling the intracellular reactive oxygen species (ROS) level through its ability to transport glutathione (a ROS scavenger) out of the cell. Moreover, we demonstrated in a mouse model that both the pharmacological inhibition and the $\Delta$ F508 mutation of CFTR lead to an impairment of the adaptive erythroid response to oxygen deprivation. We conclude that CFTR controls HIF stabilization through control of the level of intracellular ROS that act as signaling agents in the HIF-1 pathway. (Am J Pathol 2012, 181:1367-1377; http://dx.doi. org/10.1016/j.ajpath.2012.06.017)
\end{abstract}

Cystic fibrosis is the most prevalent genetic disease in the European-origin population and is commonly due to mutations of the gene encoding the protein cystic fibrosis transmembrane conductance regulator (CFTR). ${ }^{1}$ The most common mutation of CFTR, $\Delta \mathrm{F} 508$, results in the loss of a phenylalanine in position 508 within the protein. This mutation accounts for two thirds of cystic fibrosis cases worldwide. ${ }^{2}$ Moreover, the major cause of morbidity and mortality in cystic fibrosis is permanent lung injury. ${ }^{3}$ During the process, the chronic pulmonary inflammation and the consequent tissue destruction lead to progressive tissue hypoxia. Normally, tissues adapt to hypoxia by increasing the red blood cell mass (hematocrit); in cystic fibrosis patients, significant alterations in erythropoiesis are suggested by a frequent absence of adaptive polycythemia. ${ }^{4,5}$ This could be explained by an inadequate erythroid compensation for hypoxia, which suggests a role for CFTR in this physiological adaptive response. The kidney is a highly sensitive oxygen sensor and plays a central role in mediating the hypoxic induction of red blood cell production. ${ }^{6}$ Furthermore, it has been demonstrated that kidneys express large amounts of CFTR ${ }^{7}$ in the different segments of the renal tubule. We already know that one of the main pathways involved in the adaptive response to hypoxia is mediated by hypoxia-induced factor $(\mathrm{HIF})$, raising the question of a possible relationship between CFTR and the HIF-mediated hypoxic response.

The transcription factor HIF-1 is a heterodimeric molecule consisting of an inducible subunit, $\operatorname{HIF} 1-\alpha$, and a constitutively expressed subunit, $\mathrm{HIF} 1-\beta{ }^{8}$ Under normoxic conditions, oxygen-dependent prolyl-4-hydroxylases can hydroxylate proline residues at the oxygendependent degradation (ODD) domain of HIF1- $\alpha$. These modified residues form hydrogen bonds with von HippelLindau tumor suppressor protein ( $\mathrm{pVHL}$ ) side chains,

Supported by a grant (IM1020) from the French association "Vaincre la mucoviscidose" (Defeat Cystic Fibrosis).

Accepted for publication June 11, 2012

C.D. and I.R. contributed equally to this work.

Address reprint requests to Michel Tauc, Ph.D., CNRS 3472, LP2M, University of Nice-Sophia Antipolis, ParcValrose, 06108 Nice Cedex 2, France. E-mail: tauc@unice.fr. 
promoting polyubiquitination of HIF1- $\alpha$ and 26S-proteasome-mediated degradation. Hypoxia attenuates proline hydroxylation via inactivation of prolyl-4-hydroxylases in the absence of oxygen, resulting in cytosolic HIF1- $\alpha$ stabilization. The association of HIF1- $\alpha$ with the HIF1- $\beta$ subunit leads to the formation of HIF-1 complex, its nucleus translocation, and finally expression of target genes containing hypoxia responsive element sites, such as glucose transporters (GLUT-1 and GLUT-3; also known as solute carrier family 2, facilitated glucose transporter member 1 and 3 , respectively), vascular endothelial growth factor (VEGF) triggering neoangiogenesis, carbonic anhydrase IX (CAIX), ${ }^{9}$ and erythropoietin (EPO). ${ }^{10}$ The stabilization of HIF is crucial for an adequate physiological response to hypoxia.

The chronic anemia frequently observed in cystic fibrosis patients suggests a possible impairment in the metabolism of HIF1- $\alpha$ related to CFTR mutation and/or expression. Using in vitro and in vivo approaches, we demonstrate that CFTR is involved in the stabilization of HIF1- $\alpha$ via control of the level of intracellular reactive oxygen species (ROS) generated during hypoxia.

\section{Materials and Methods}

\section{Cell Culture and Hypoxic Experimental Conditions}

The primary cell culture technique has been described in detail previously. ${ }^{7,11}$ In brief, proximal convoluted tubules (PCT) from C57BL/6 mouse kidneys were microdissected and maintained in Dulbecco's modified Eagle's medium/ Ham's F12 nutrient mixture (DMEM-F12; Sigma-Aldrich, St. Louis, MO). The immortalized cell line was obtained from 10-day-old primary cultures of PCT transfected with pSV3 neo vector. ${ }^{12}$ Cultures were classically maintained in a water-saturated atmosphere of $5 \% \quad \mathrm{CO}_{2} / 95 \%$ air. Hypoxic conditions were obtained by maintaining the cell culture at $37^{\circ} \mathrm{C}$ in a sealed anaerobic workstation (Bugbox; Ruskin Technologies, Bridgend, UK) with low oxygen concentration in the atmosphere $\left(5 \% \mathrm{O}_{2} / 5 \%\right.$ $\left.\mathrm{CO}_{2} / 90 \% \mathrm{~N}_{2}\right)$. $\mathrm{H}$ fetal calf serum K-2 proximal tubule epithelial cells (a gift from Dr. Eric Rondeau) were cultured in DMEM-F12 culture medium supplemented with $10 \%$ SVF. ${ }^{13}$

\section{Western Blotting}

PCT or HK-2 cell lysates were prepared in ice-cold lysis buffer. ${ }^{14}$ Equivalent amounts of protein per lane $(60 \mu \mathrm{g})$ were separated by SDS-PAGE on $8.5 \%$ polyacrylamide gels. The membranes were probed with primary anti-HIF (dilution 1:1000; R\&D Systems, Minneapolis, MN), antiCA-IX (dilution 1:1000; R\&D Systems), and mouse anti$\beta$-actin antibodies (dilution 1:2000; Sigma-Aldrich) and then were probed with horseradish peroxidase-conjugated secondary antibody (dilution 1:2000; Dako, Glostrup, Denmark). Western blots were revealed using enzymatic chemiluminescence solution (Millipore, Billerica, MA) and were quantified using ImageJ software version $1.44(\mathrm{NIH}$, Bethesda, MD).

\section{Engineering of the Hypoxia Reporter Cell System}

The ODD domain of HIF-1- $\alpha$ is responsible for the proteasomal degradation of HIF-1- $\alpha$ under normoxic conditions. It has been located to the amino acid residues 401 to 603 of human HIF-1. This domain overlaps with a VHL binding domain (amino acids 526 to 641) and comprises two essential proline residues, Pro-402 and Pro-564, that are hydroxylated by prolyl-4-hydroxylases under normoxic conditions. We generated a chimeric protein in which the C-terminal part of the ODD region of human HIF-1- $\alpha$ (residues 530 to 603) was fused to the GFP open reading frames. A 222-bp DNA fragment corresponding to amino acids 530 to 603 (nucleotides 1616 to 1837) of human HIF-1 was PCR-amplified using the sense primer 5'CCGCTCGAGGCCACCATGGAATTCAAGTTGGAATTGGTA-3' and the antisense primer 5'-GCTCTAGACTGGAATACTGTAAC- $5^{\prime}$. The product was digested by Xhol and Xbal and was fused in-frame with the enhanced GFP of a Xhol/Xbal-digested pCl-eGFP2 plasmid. The fused sequence includes the Pro-564 residue that is hydroxylated by prolyl hydroxylases. ${ }^{15,16}$ The product was digested by Nhel and Notl and was inserted into the Nhel/EcoRVdigested pIREShyg3 vector (Invitrogen, Carlsbad, CA). Stable ODD-GFP transfectants were obtained using proximal PCT cells transfected using a mixture of $2 \mu \mathrm{g}$ plasmid DNA (ODD-GFP containing pIREShyg3 vector (Invitrogen) and $6 \mu \mathrm{L}$ of FuGENE transfection reagent (Roche Applied Science, Indianapolis, IN). Stable transfectants were selected using hygromycin $(1 \mathrm{mg} / \mathrm{mL})$.

Time courses of ODD-GFP accumulation in the transfected cells were measured using a video fluorescence system coupled with a high-sensitivity video camera (ISIS-3; Photonic Science, Robertsbridge, UK). Images $(510 \mathrm{~nm})$ were acquired every 30 minutes over a period of 20 to 24 hours. The temperature and the oxygen concentration were controlled throughout each experiment.

\section{Measurement of Intracellular GSH and ROS Production}

Glutathione (GSH) content was quantified using a fluorescent GSH/GSSG assay kit (BioVision, Mountain View, $\mathrm{CA}$ ) in confluent cells (35-mm Petri dishes), according to the manufacturer's protocol. Intracellular ROS production was quantified using a fluorescent probe [5-(and-6)-carboxy-2', $7^{\prime}$-dichlorodihydrofluorescein diacetate (carboxy- $\mathrm{H}_{2}$ DCFDA) (Molecular Probes; Invitrogen)]. Cells were incubated for 30 to 60 minutes in the presence of carboxy- $\mathrm{H}_{2}$ DCFDA $(10 \mu \mathrm{mol} / \mathrm{L})$. After a wash, the fluorescence variations were measured every 2 minutes using video microscopy (Imaging Workbench version 2.1; Axon Instruments Inc, Union City, CA).

\section{Electrophysiological Studies}

The ruptured whole-cell configuration of the patch-clamp technique was used to assess functional expression of CFTR. PCT cells were held at $-50 \mathrm{mV}$, and $400-\mathrm{ms}$ pulses from -100 to $+100 \mathrm{mV}$ were applied in $20-\mathrm{mV}$ increments. The pipette solution contained (in $\mathrm{mmol} / \mathrm{L}$ ) 
$140 \mathrm{~N}$-methyl-D-glucamine chloride, 10 HEPES ( $\mathrm{pH} 7.4$ ), 5 EGTA, and 5 magnesium ATP (Pos $=290 \mathrm{mOsm} / \mathrm{kg}$ $\mathrm{H}_{2} \mathrm{O}$ ). The bath solution ( 315 to $320 \mathrm{mOsm} / \mathrm{kg} \mathrm{H}_{2} \mathrm{O}$ ) was composed of DMEM-F12 culture medium supplemented with $20 \mathrm{mmol} / \mathrm{L}$ HEPES (pH 7.4). Hypoxic experimental conditions were obtained by applying a continuous laminar gas flux $\left(5 \% \mathrm{O}_{2} / 95 \% \mathrm{~N}_{2}\right)$ over the surface of the Petri dish throughout the experiment. Control experiments were performed using a normoxic gas mixture $\left(20 \% \mathrm{O}_{2} /\right.$ $80 \% \mathrm{~N}_{2}$ ). Cell currents and cell capacitances were recorded using an EPC 10 amplifier (HEKA Electronik, Lambrecht/Pfalz, Germany). Conductance $(G=I / M)$ relationships were expressed as mean current densities.

\section{Immunolocalization of CFTR}

To demonstrate evidence of CFTR expression, PCT cell lines grown on glass coverslips were incubated in a hypoxia chamber $\left(5 \% \mathrm{O}_{2}\right)$ for 1 and 6 hours. Cells were washed in PBS, fixed in paraformaldehyde (3.7\%) at room temperature for 15 minutes, and blocked using PBS- $\mathrm{NH}_{4} \mathrm{Cl}(5 \mathrm{mmol} / \mathrm{L})$ for 15 minutes. Cells were then permeabilized with PBS/0.3\% Triton X-100 for 5 minutes and blocked for 20 minutes with saturation buffer $(0.03 \%$ Triton $\mathrm{X}-100,2.5 \%$ goat serum, $1 \%$ bovine serum albumin, and $0.2 \%$ gelatin in PBS). This saturation buffer was used throughout the experiment. Cells were incubated overnight with anti-CFTR antibodies at $4^{\circ} \mathrm{C}$ (M3A7, UBI 05-583, 4 $\mu \mathrm{g} / \mathrm{mL}$; Millipore), washed with PBS $0.3 \%$, and revealed with fluorescein isothiocyanate-conjugated anti-mouse (1: 500; Molecular Probes; Invitrogen) antibodies and phalloidin-tetramethylrhodamine isothiocyanate (TRITC; 1:1000; Sigma-Aldrich) for 1 hour at room temperature.

\section{Identification of CFTR mRNA in the HK-2 Cell Line}

Total RNA was prepared from the HK-2 cell line using a NucleoSpin RNA II kit (Macherey-Nagel, Düren, Germany). cDNA synthesis was performed using a SuperScript first-strand synthesis system for RT-PCR (Invitrogen) according to the manufacturer's instructions. cDNA specific for CFTR was amplified using oligonucleotide primers giving rise to product of $401 \mathrm{bp}$ (CFTR sense: 5'-AAGCTGTCAAGCCGTGTTCT-3'; CFTR antisense: 5'-GCCTTCCGAGTCAGTTTCAG-3').

$$
\text { CFTR }_{\text {inh }}-172
$$

CFTR inh $^{-172}$ was purchased from Sigma-Aldrich (C2992). A $20 \mathrm{mmol} / \mathrm{L}$ stock solution was prepared in dimethyl sulfoxide (DMSO). For in vitro experiments, final dilution was performed directly in culture medium at $5 \mu \mathrm{mol} / \mathrm{L}$ (final DMSO concentration, $0.025 \%$ ). All control experiments were performed with vehicle only.

\section{In Vivo Exposure to Hypoxia in Animal Groups}

Mice (male, 7 to 8 weeks of age) were housed in a temperature-controlled room under a 12-hour light/dark cycle with free access to water and standard mouse chow. The use of animals was approved by the local ethics committee and was in accord with the Guide for the Care and Use of Laboratory Animals (8th edition, 2011).

The first set of experiments was performed on 40 mice of the C57BL/6NRj strain (Janvier-Europe, Saint Berthevin, France) that were randomly and equally distributed across four experimental groups. In brief, the animals received an intraperitoneal injection of CFTR inh $^{-172}$ or vehicle only ( $0.9 \%$ normal saline solution containing $1 \%$ DMSO) and were maintained for 24 hours under normoxic or hypoxic conditions. Before the injection, CFTR inh $^{-172}$ was dissolved at $20 \mathrm{mg} / \mathrm{mL}$ in DMSO and was administered at 1 $\mathrm{mg} / \mathrm{kg}$ body weight in $0.9 \%$ normal saline solution (final DMSO concentration, 1\%). The mice exposed to hypoxia $\left[8 \% \mathrm{O}_{2}\right.$ (in vivo experiments) $/ 92 \% \mathrm{~N}_{2}$ (in vitro experiments)] were maintained in an air-tight hypoxia chamber and the $\mathrm{O}_{2}$ concentration was continuously monitored and adjusted accordingly.

In a second set of experiments, wild-type (WT; FVB background) or homozygous $\Delta$ F508-mice (European Mouse Mutant Archive-EMMA, Orleans, France) were divided into four groups and were maintained for 24 hours under normoxia (room air; 19 WT and $13 \Delta$ F508-CFTR mice) or hypoxia (8\% $\mathrm{O}_{2} / 92 \% \mathrm{~N}_{2} ; 19 \mathrm{WT}$ and $19 \Delta \mathrm{F} 508$ CFTR mice), as described in Materials and Methods.

Urine of animals was collected via spontaneous voiding, and blood samples were obtained via retro-orbital bleeding. Hematocrit was classically measured after centrifugation of the capillary tubes.

\section{Statistical Analysis}

Data are expressed as means \pm SEM. Student's $t$-test or analyses of variance followed by Tukey's multiple comparison test were used.

\section{Results}

\section{Inhibition of CFTR Impairs HIF1- $\alpha$ Stabilization}

Cytosolic stabilization of the transcriptional activator HIF1- $\alpha$ is a prerequisite to an adaptive response to hypoxia. Thus, we first investigated the effect of the CFTR inhibitor $\left(\mathrm{CFTR}_{\text {inh }}{ }^{172}\right)$ on the intracellular HIF1- $\alpha$ accumulation triggered by hypoxia. As expected, Western blotting experiments performed on renal cultured cells revealed no HIF1- $\alpha$ expression under normoxic conditions in the presence or absence of CFTR inh $^{-172}$ (Figure 1A). By contrast, hypoxia $\left(5 \% \mathrm{O}_{2}\right)$ induced a huge increase of HIF1- $\alpha$ expression after 20 hours. This stabilization of HIF1- $\alpha$ was significantly decreased in the presence of CFTR $\mathrm{inh}^{-172}$ $(P<0.01)$, as shown by densitometric analysis of the immunoblots (Figure 1, A and B). What is interesting is that the addition of the ROS scavenger $\mathrm{N}$-acetylcysteine (NAC; $10 \mathrm{mmol} / \mathrm{L}$ ) during hypoxia impaired HIF1- $\alpha$ stabilization, suggesting an important role for ROS in this process. It is well known that CFTR could be activated through CAMP dependent signaling pathway, and we therefore looked for a direct effect of forskolin on HIF1- $\alpha$ stabilization. Western blot analysis performed under normoxic conditions (Figure 1C) demonstrated that CAMP- 

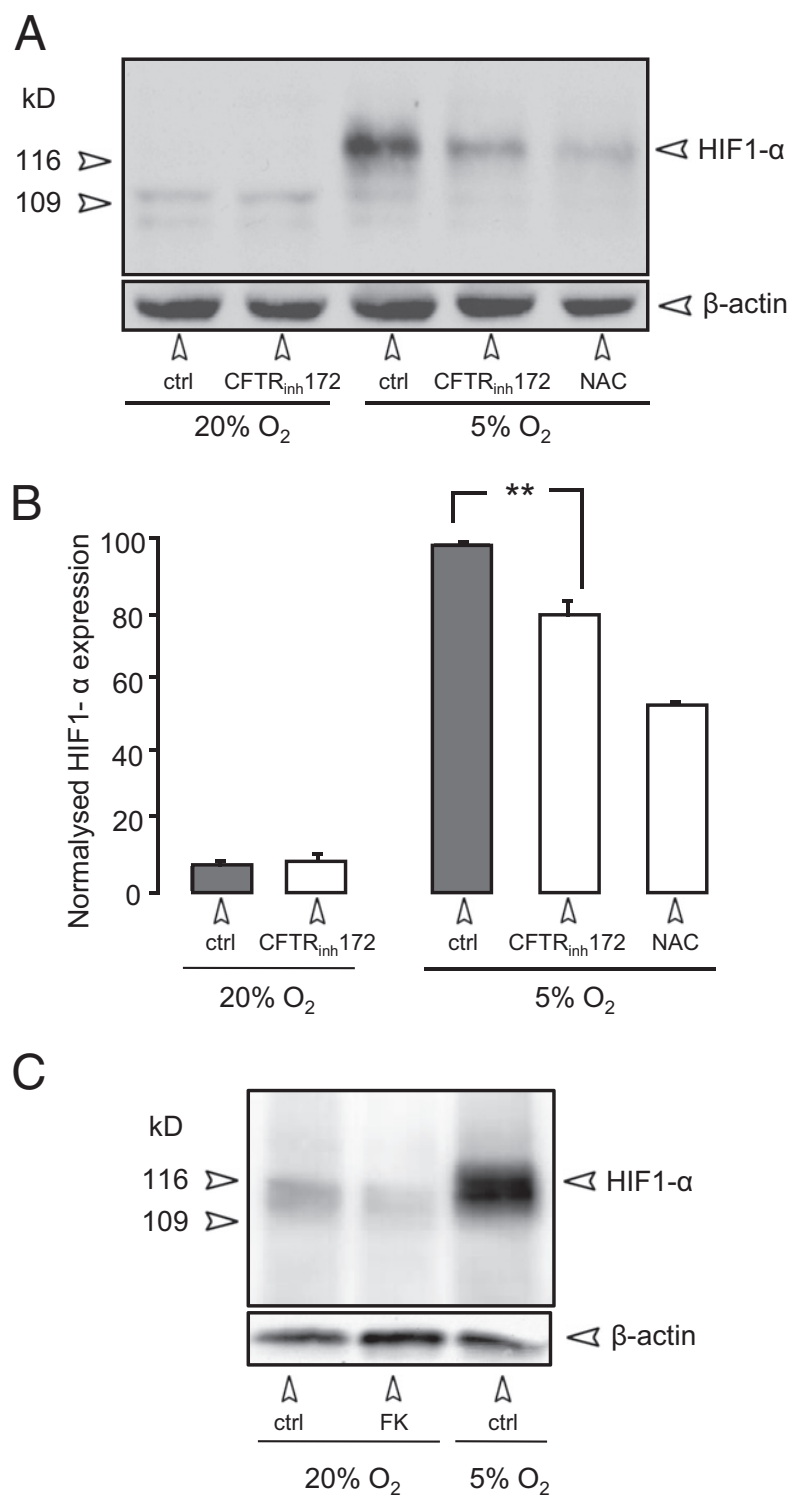

Figure 1. Effect of CFTR -172 on hypoxia-induced HIF-1 stabilization in PCT cells. A: Cell lysates from PCT cells exposed to normoxia $\left(20 \% \mathrm{O}_{2}\right)$ or hypoxia $(5 \%$ $\mathrm{O}_{2}$ ) for 24 hours were analyzed by SDS-PAGE and immunoblotting to reveal the HIF1- $\alpha$ level. Cells were cultured in the absence or presence of CFTR $\mathrm{inh}-172$ $(5 \mu \mathrm{mol} / \mathrm{L})$ or $\mathrm{NAC}(10 \mathrm{mmol} / \mathrm{L})$. The blots were probed for $\beta$-actin, to monitor protein loading and transferring. B: The level of HIF1- $\alpha$ measured under normoxia or hypoxia in the absence or presence of $\mathrm{CFTR}_{\text {inh }}-172(5 \mu \mathrm{mol} / \mathrm{L})$ or NAC (10 $\mathrm{mmol} / \mathrm{L}$ ). For each experimental condition, the results were normalized to the maximum HIF1- $\alpha$ level (100\%) obtained under hypoxic conditions after 24 hours. C: Effect of forskolin in PCT cells under normoxic conditions. Cell lysates from PCT cells exposed to normoxia for 24 hours were analyzed by SDS-PAGE and immunoblotting to reveal the HIF-1- $\alpha$ level. Cells were either left untreated or were treated with forskolin $(10 \mu \mathrm{mol} / \mathrm{L})$ for 24 hours. Positive control was performed in parallel by exposing PCT cells to hypoxia for 24 hours. Blots were probed for $\beta$-actin, to monitor protein loading and transferring. Data are expressed as means \pm SEM of five independent Western blots. ${ }^{* * *} P<0.01$ Student's $t$-test. FK, forskolin.

mediated stimulation of CFTR is not sufficient to increase HIF1- $\alpha$ stabilization.

\section{Dynamic Monitoring of the Cell Response to Hypoxia}

To monitor the adaptive response to hypoxia in real time, we decided to engineer a cell reporter system based on the hypoxic stabilization of the chimeric protein ODDGFP $^{17}$ with the human HIF-1- $\alpha$ ODD encoding sequence fused to the GFP open reading frame. Stable mouse kidney PCT cells expressing ODD-GFP were engineered. Expression of ODD-GFP during hypoxia was monitored by fluorescence video microscopy. A representative example of the ODD-GFP fluorescence emitted by immortalized PCT cells exposed for 24 hours to normoxia (20\% $\mathrm{O}_{2}$ ) or hypoxia $\left(5 \% \mathrm{O}_{2}\right)$ is shown in Figure $2 \mathrm{~A}$. Inhibition of proteasome activity by MG132 [C2211] induced a maximal stabilization and accumulation of ODD-GFP protein in the reporter cell line. The time course of ODD-GFP stabilization was measured in the presence of MG132 (10 $\mu \mathrm{mol} / \mathrm{L})$, in the presence of cobalt (100 $\mu \mathrm{mol} / \mathrm{L})$, which inhibits proline hydroxylation, and finally under normoxic $\left(20 \% \mathrm{O}_{2}\right)$ and hypoxic conditions $\left(5 \% \mathrm{O}_{2}\right)$ (Figure $\left.2 \mathrm{~B}\right)$. Under all conditions, a maximum in ODD-GFP stabilization was obtained between 18 and 20 hours. These data demonstrate that this cell reporter system is highly sensitive to the classical HIF1- $\alpha$ inducers, including hypoxia. The accumulation of ODD-GFP under hypoxic conditions $\left(5 \% \mathrm{O}_{2}\right)$ for 20 hours in the presence or absence of CFTR $_{\text {inh }}-172$ was evaluated (Figure 2C). CFTR inh $^{-172}$ had only a negligible effect under normoxic conditions, but significantly decreased the level of ODD-GFP stabilized after exposure to hypoxia for 20 hours $(P<0.01)$ : $78.66 \pm 4.28 \%$ for hypoxia alone and $53.07 \pm 2.33 \%$ for both hypoxia and CFTR $_{\text {inh }}-172$, where results are expressed in percentage of the response obtained in the presence of MG132 that reflects the maximum ODD-GFP fluorescence reached with a complete blockage of the proteasome degradation pathway.

\section{CFTR Modulates the Intracellular GSH Content and ROS Production during Hypoxia}

In addition to its conventional permeability to $\mathrm{Cl}^{-}$, various studies have shown that CFTR can mediate the transport of reduced $\mathrm{GSH}^{18-20}$ Because $\mathrm{GSH}$ is a major ROS scavenger, we hypothesized that activation of CFTR under hypoxic conditions is related to a decrease of intracellular GSH content and probably to a hypoxia-induced rise in intracellular ROS level. We found that exposing PCT cells to hypoxia $\left(5 \% \mathrm{O}_{2}\right)$ induced a significant decrease (29 $\pm 5 \% ; P<0.01 ; n=9)$ in the intracellular GSH content (Figure 3A), which was largely prevented by addition of CFTR inh $^{-172}$. This result confirms the crucial role of CFTR in the modulation of intracellular GSH level in response to hypoxic stress.

To investigate the importance of the decrease in GSH content on the redox state of renal cells subjected to hypoxic stress, we analyzed the intracellular ROS production using the fluorescent probe carboxy- $\mathrm{H}_{2}$ DCFDA. The time course of ROS production during hypoxia in different conditions was measured (Figure 3B), and the initial slope of ROS production measured under normoxic or hypoxic conditions in the presence or absence of CFTR inh $^{-172}$ was calculated (Figure 3C). Inhibition of CFTR largely prevented the intracellular production of ROS induced by hypoxia. As positive control of ROS 
production (Figure 3B), we exposed PCT cells to staurosporine (STS; $5 \mu \mathrm{mol} / \mathrm{L}$ ), a strong apoptotic inducer known to generate massive ROS production. ${ }^{19,21}$

\section{Hypoxia-Induced CFTR Cl- Currents in PCTS}

Given the demonstrated important role of CFTR in GSH and ROS levels, we investigated the functional expres-
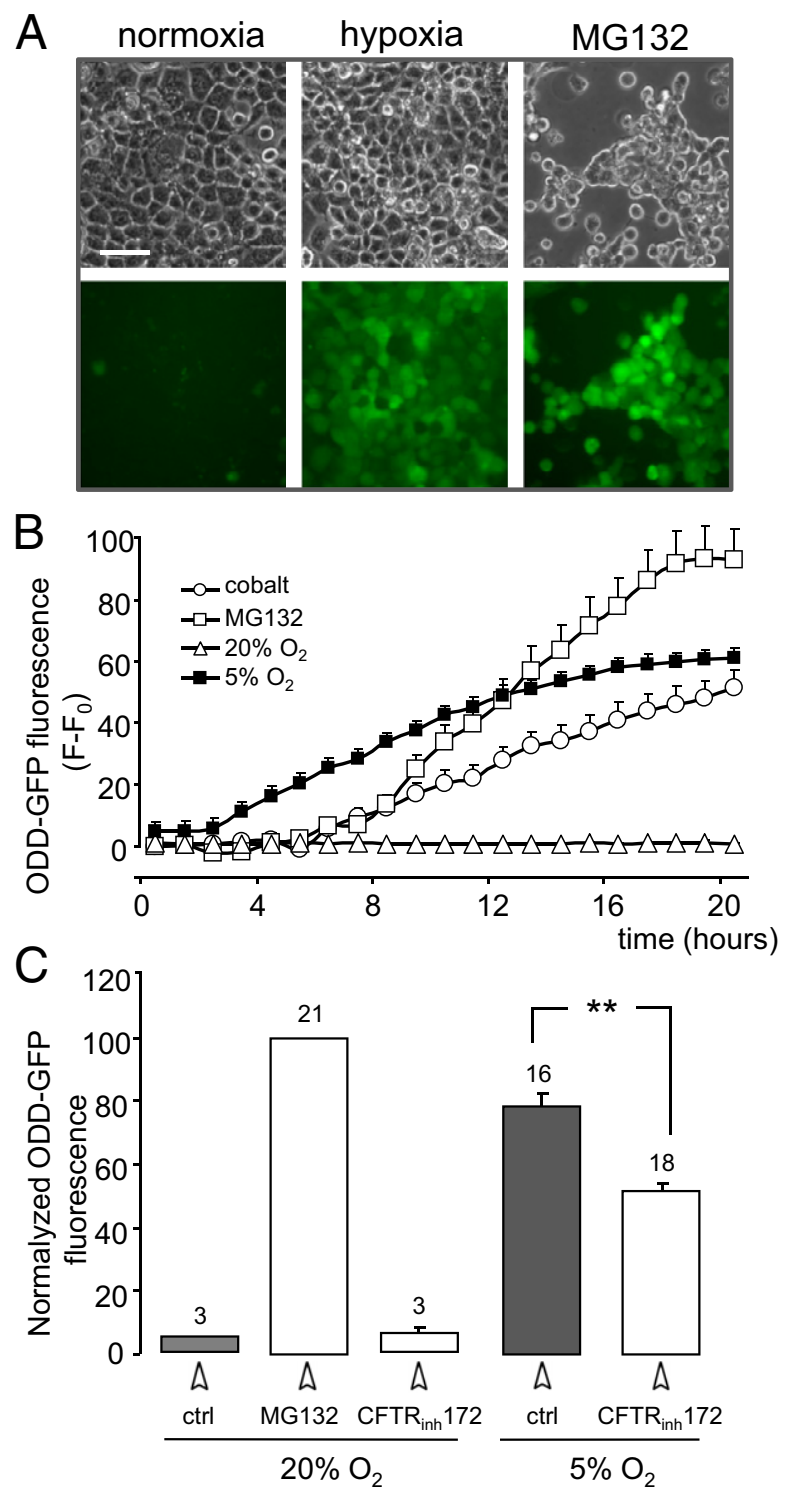

Figure 2. Effect of hypoxia on the stabilization of the ODD-GFP chimeric protein in PCT cells. A: Phase-contrast (top row) and fluorescence (bottom row; $510 \mathrm{~nm}$ ) images obtained from PCT ODD-GFP transfected cells were maintained under normoxia $\left(20 \% \mathrm{O}_{2}\right)$ or hypoxia $\left(5 \% \mathrm{O}_{2}\right)$ for 24 hours. A positive control was performed by exposing the cells to the proteasome inhibitor MG132 $(10 \mu \mathrm{mol} / \mathrm{L})$. B: Kinetics of stabilization of the chimeric protein ODD-GFP recorded in PCT transfected cells maintained under normoxia, in the presence of MG132 $(10 \mu \mathrm{mol} / \mathrm{L})$ or cobalt $(100 \mu \mathrm{mol} / \mathrm{L})$, or under hypoxia. The fluorescence value $(F)$ minus the fluorescence value at $t=0\left(F_{0}\right)$ was plotted against time. C: Normalized ODD-GFP fluorescence was measured under normoxia or hypoxia in the absence or presence of $\mathrm{CFTR}_{\mathrm{inh}}-172(5 \mu \mathrm{mol} / \mathrm{L})$. Values were normalized to the maximum value of fluorescence recorded after 20 hours in the presence of MG132 (10 $\mu \mathrm{mol} / \mathrm{L}$ ). Values are normalized and expressed as a percentage of the maximum value obtained with MG132 which is equal to $100 \%$. Data are expressed as means \pm SEM. ${ }^{* * *} P<0.01$ Student's $t$-test. Scale bar $=30 \mu \mathrm{m}$.
A
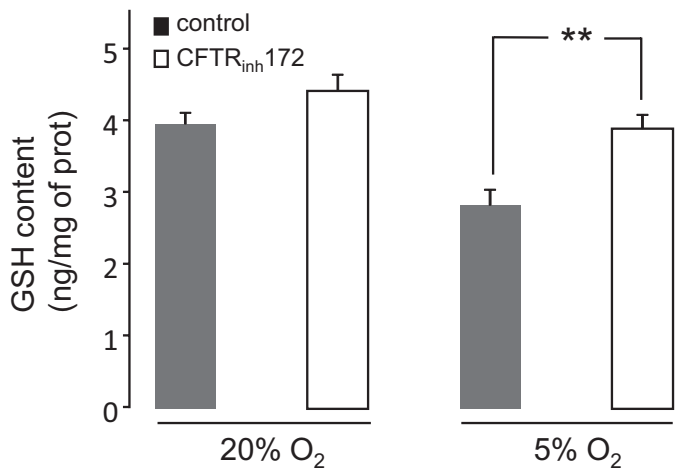

B
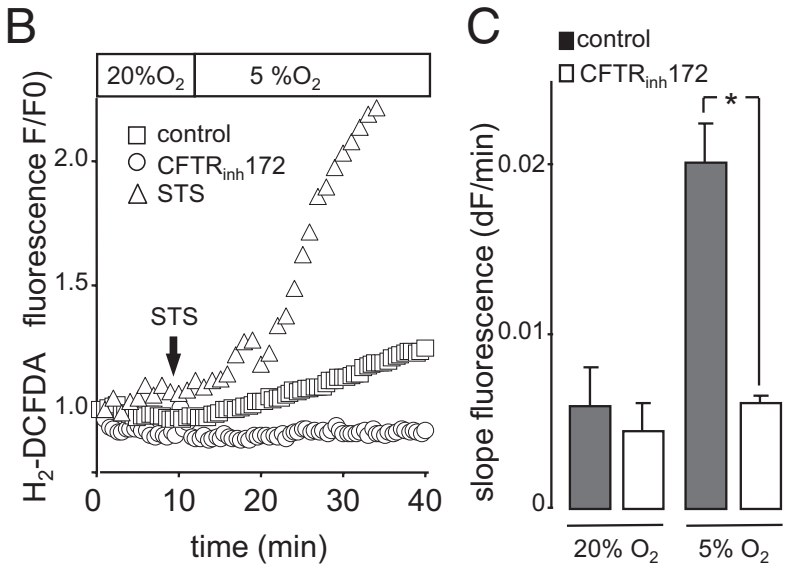

Figure 3. Effect of CFTR inhibition on intracellular GSH and oxidative status. A: Intracellular GSH was measured using OPA fluorescence probe in PCT cells exposed to normoxia $\left(20 \% \mathrm{O}_{2}\right)$ or hypoxia $\left(5 \% \mathrm{O}_{2}\right)$ for 12 hours in the presence or absence of $\mathrm{CFTR}_{\mathrm{inh}}-172(5 \mu \mathrm{mol} / \mathrm{L})$. B: Time course of ROS increase in PCT cells exposed to normoxia or hypoxia in the absence (control) or presence of $\mathrm{CFTR}_{\mathrm{inh}^{-}}-172(5 \mu \mathrm{mol} / \mathrm{L})$. Primary cultures were loaded with carboxy- $\mathrm{H}_{2}$ DCFDA $(10 \mu \mathrm{mol} / \mathrm{L})$ for 1 hour, and the fluorescence was recorded at $510 \mathrm{~nm}$. After a control period of 10 minutes performed under normoxia, the cells were exposed to hypoxia. Addition of the chemical apoptosis inducer staurosporine (STS; $5 \mu \mathrm{mol} / \mathrm{L}$ ) induced an uncontrolled, huge increase in ROS production. C: Mean initial slopes recorded under normoxic or hypoxic conditions in the absence or presence of $\mathrm{CFTR}_{\mathrm{inh}}-172$ $(5 \mu \mathrm{mol} / \mathrm{L})$. Data are expressed as means \pm SEM of six individual experiments (A) or of 30 to 40 independent cells analyzed from four independent cultures $(\mathbf{C}) .{ }^{*} P<0.05$; ${ }^{* * *} P<0.01$ Student's $t$-test.

sion of CFTR triggered by hypoxia. To determine the presence of any functional CFTR in the plasma membrane, whole-cell $\mathrm{Cl}^{-}$currents were classically recorded in immortalized PCT cells with $140 \mathrm{mmol} / \mathrm{L} N$-methyl-Dglucamine chloride solution in the pipette and $\mathrm{NaCl}$ culture medium in the bath. Cells were exposed to normoxia $\left(20 \% \mathrm{O}_{2} / 80 \% \mathrm{~N}_{2}\right)$ or hypoxia $\left(5 \% \mathrm{O}_{2} / 95 \% \mathrm{~N}_{2}\right)$ by application of a continuous laminar gas flux over the surface of the Petri dish throughout the experiments. Individual cells were clamped at different times after the beginning of laminar gas flux exposure. Under hypoxic conditions and during the first 40 minutes, the voltage-step protocol elicited only small currents (Figure 4A), with a mean slope conductance of $0.349 \pm 0.069 \mathrm{nS} / \mathrm{pF}$ (Figure 4D). After 40 minutes of hypoxia $\left(5 \% \mathrm{O}_{2} / 95 \% \mathrm{~N}_{2}\right)$, higher $\mathrm{Cl}^{-}$currents were recorded (Figure $4, \mathrm{~B}$ and $\mathrm{C}$ ). The mean slope conductance was $0.807 \pm 0.2 \mathrm{nS} / \mathrm{pF}$ (Figure 4D). These hypoxia-induced currents were inhibited largely by $\mathrm{CFTR}_{\text {inh }}-172$ and by the nonselective $\mathrm{Cl}^{-}$channel inhibitor 5-nitro-2-(3-phenylpropylamino)benzoic acid (NPPB; 100 

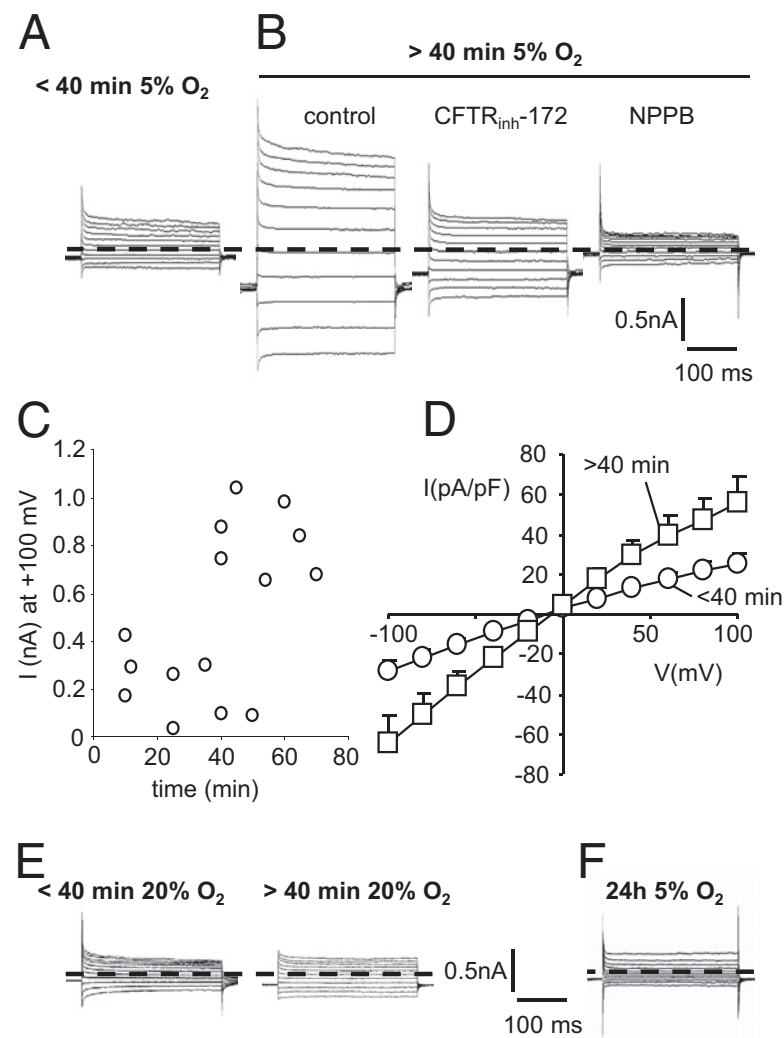

Figure 4. Effect of hypoxia on the $\mathrm{CFTR} \mathrm{Cl}^{-}$currents in PCT cells. Wholecell $\mathrm{Cl}^{-}$currents were recorded after different durations of exposure to hypoxia ( $\mathbf{A}$ and $\mathbf{B})$ or normoxia $(\mathbf{E}$ and $\mathbf{F})$. Membrane potential was held at $-50 \mathrm{mV}$, and currents were elicited by a train of 11 voltage steps (400-ms duration) between -100 and $+100 \mathrm{mV}$. The effect of $\mathrm{CFTR}_{\mathrm{inh}}-172(5 \mu \mathrm{mol} / \mathrm{L})$ or natriuretic peptides $\mathrm{B}(\mathrm{NPPB} ; 100 \mu \mathrm{mol} / \mathrm{L})$ was tested on the hypoxiastimulated $\mathrm{Cl}^{-}$current (B). C: $\mathrm{Cl}^{-}$current values recorded at $+100 \mathrm{mV}$ as a function of the exposure time to hypoxia. Cells were maintained permanently under hypoxia as in $\mathbf{A}$ and $\mathbf{B}$, and $\mathrm{Cl}^{-}$currents were recorded at different times. Each data point represents an individual whole-cell recording $(n=15)$ that has been analyzed sequentially (as in $\mathbf{B}$ ). The statistical trace analysis revealed a critical time of exposure to hypoxia ( 40 minutes) necessary to activate CFTR $\mathrm{Cl}^{-}$currents. D: Mean current densities (corresponding to the whole-cell traces in $\mathbf{A}$ and $\mathbf{B}$ ) for short $(<40$ minutes; $n=6$ ) and long ( $>40$ minutes; $n=9$ ) exposure times. Data are expressed as means \pm SEM.

$\mu \mathrm{mol} / \mathrm{L})$ (Figure 4B). Under normoxic conditions $\left(20 \% \mathrm{O}_{2} /\right.$ $80 \% \mathrm{~N}_{2}$ ), no significant $\mathrm{Cl}^{-}$currents could be recorded (Figure $4 \mathrm{E}$ ), irrespective of incubation time, confirming the activating role of hypoxia. Patch-clamp experiments performed after 24 hours of hypoxia $\left(5 \% \mathrm{O}_{2} / 95 \% \mathrm{~N}_{2}\right)$ did not reveal any significant presence of $\mathrm{CFTR} \mathrm{Cl}^{-}$currents (Figure $4 \mathrm{~F}$ ), and the voltage-step protocol elicited only small currents with a mean slope conductance of $0.130 \pm$ $0.089 \mathrm{nS} / \mathrm{pF}(n=4)$. Taken together, these results indicate that hypoxia was able to activate $\mathrm{CFTR} \mathrm{Cl}^{-}$currents in the early response to hypoxia only.

\section{Hypoxia-Induced CFTR Expression in PCTs}

To determine CFTR expression during hypoxia, we performed immunohistochemical labeling of CFTR (Figure 5). Under normoxic conditions, anti-CFTR antibody revealed only a weak labeling (Figure 5, A and B). By contrast, exposing cells to hypoxia for 1 to 6 hours induced a marked increase in CFTR expression (Figure 5, C-F). No anti-CFTR staining could be observed when the first CFTR antibody was omitted from the incubation medium (Figure 5, G and $\mathrm{H}$ ), confirming the specificity of the CFTR antibody. These data indicate that hypoxia-induced CFTR $\mathrm{Cl}^{-}$currents resulted from an increase in the plasma membrane expression of CFTR, rather than from a modification in the kinetic parameters of pre-existing CFTR Cl${ }^{-}$channels.
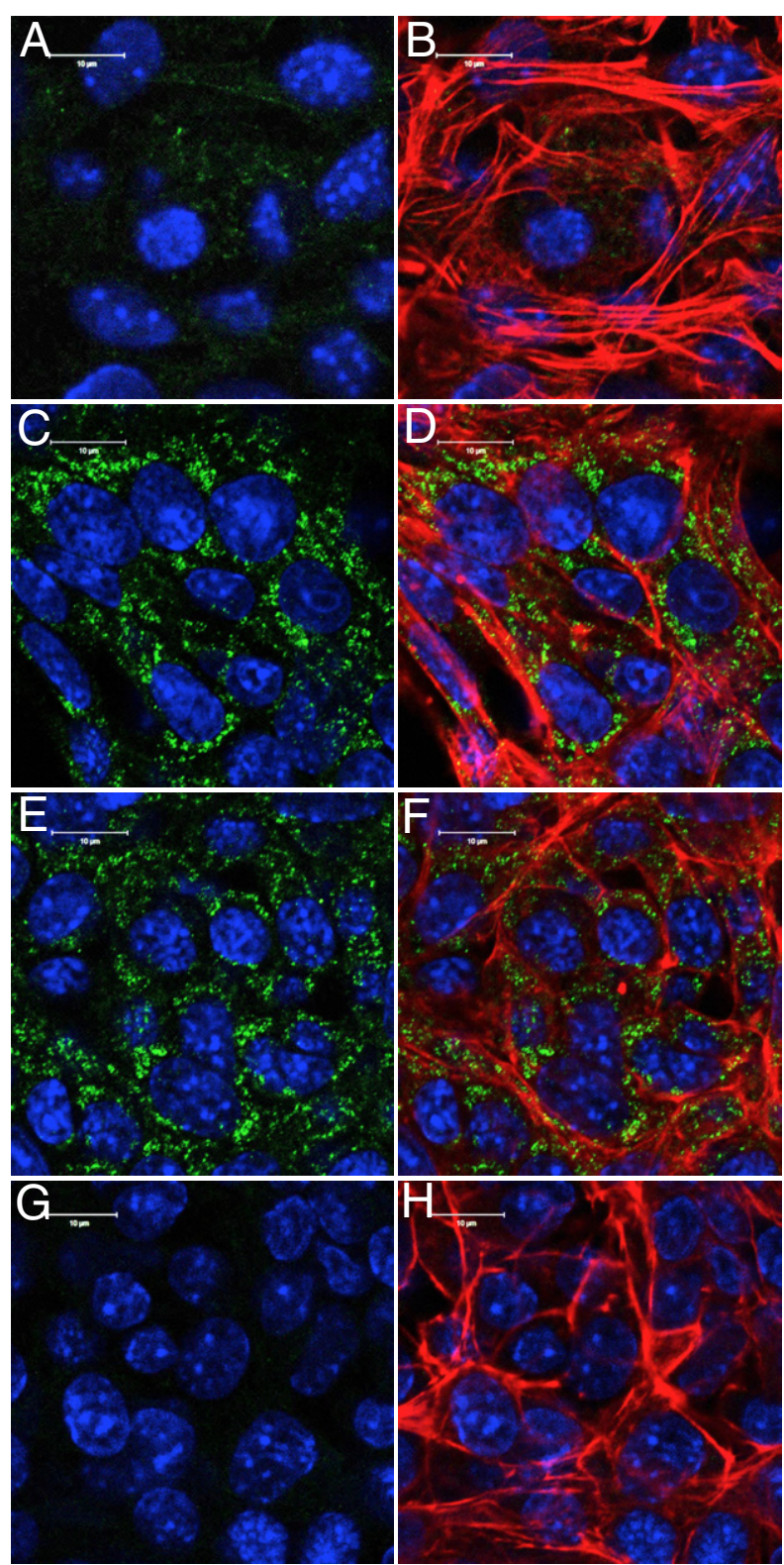

Figure 5. Effect of hypoxia on CFTR and actin expression. For immunolocalization of CFTR in PCT cells fixed with paraformaldehyde, PCT cells were exposed to normoxia $\left(20 \% \mathrm{O}_{2}\right)(\mathbf{A}$ and $\mathbf{B})$ or hypoxia $\left(5 \% \mathrm{O}_{2}\right)$ for 1 hour $(\mathbf{C}$ and $\mathbf{D}$ ) or hypoxia for 6 hours (E and $\mathbf{F}$ ) and were processed for immunodetection with anti-CFTR (green). The actin network was labeled with phalloidin-tetramethylrhodamine isothiocyanate (red). Negative control experiments were performed after 6 hours of hypoxia under the same conditions except for the presence of anti-CFTR antibodies $(\mathbf{G}$ and $\mathbf{H})$. Nuclei were stained with Hoechst 33258 dye (blue). Scale bar $=10 \mu \mathrm{m}$. 


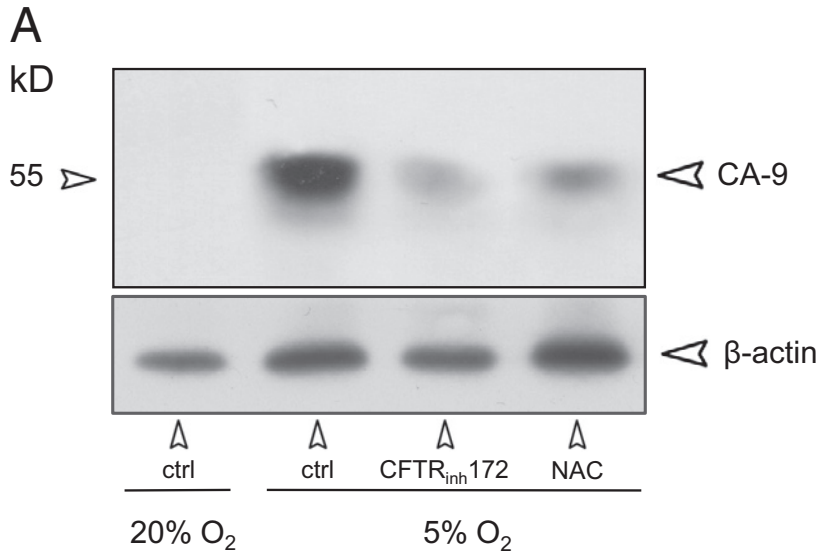

B

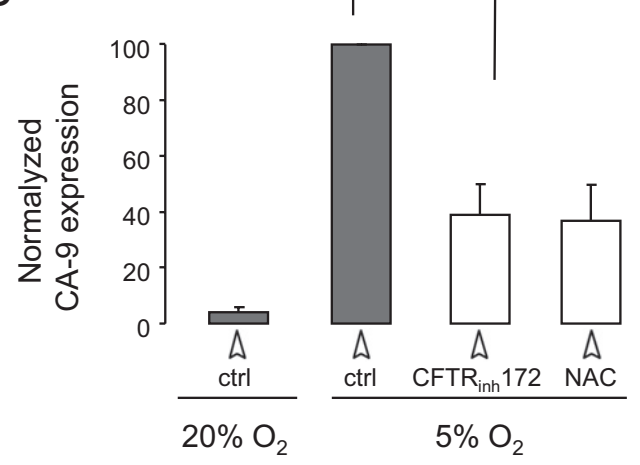

Figure 6. Effect of $\mathrm{CFTR}_{\mathrm{inh}}-172$ and NAC on hypoxia-induced CA-IX expression in PCT cells. A: Cell lysates from PCT cells exposed to normoxia (20\% $\left.\mathrm{O}_{2}\right)$ or hypoxia $\left(5 \% \mathrm{O}_{2}\right)$ for 24 hours were analyzed by SDS-PAGE and immunoblotting to reveal CA-IX expression. Cells were cultured in the absence or presence of $\mathrm{CFTR}_{\mathrm{inh}}-172(5 \mu \mathrm{mol} / \mathrm{L})$ or NAC $(10 \mathrm{mmol} / \mathrm{L})$. The blots were reprobed for $\beta$-actin expression, to monitor protein loading and transferring. B: The level of CA-IX expression was determined under normoxic and hypoxic conditions, in the absence or presence of $\mathrm{CFTR}_{\mathrm{inh}}-172(5$ $\mu \mathrm{mol} / \mathrm{L})$ or $\mathrm{NAC}(10 \mathrm{mmol} / \mathrm{L})$. For each experimental condition, the results were normalized to the maximum of CA-IX level (100\%) obtained under hypoxic conditions after 24 hours. Data are expressed as means \pm SEM of five independent Western blots.

\section{Role of CFTR on the HIF1 Target Protein CA-IX}

Carbonic anhydrase IX is expressed in a limited number of normal tissues and is invariably linked with the hypoxic phenotype. ${ }^{22}$ Expression of CA-IX was analyzed by western blotting in PCT cells. Under normoxic conditions, CA-IX exhibited a very weak level of expression, but expression was strongly increased under hypoxic conditions $\left(5 \% \mathrm{O}_{2}\right)$ for 20 hours (Figure $\left.6 \mathrm{~A}\right)$. Addition of CFTR $_{\text {inh }}-172$ impaired the expression of CA-IX by approximately $30 \%$, as shown by densitometric analysis of the immunoblots (Figure 6B). Interestingly, addition of the ROS scavenger NAC (10 mmol/L) during hypoxia drastically impaired the expression of CA-IX.

\section{Pharmacological Inhibition of CFTR or CFTR- $\Delta F 508$ Mutation Prevents the Adaptive Response to Hypoxia in Mouse Models in Vivo}

In mammals, the main physiological response to hypoxia leads to an increase in the red blood cell mass (hemat- ocrit). To examine the relevance of CFTR inhibition on this HIF-mediated physiological process, we measured hematocrit variation in WT mice (C57BL/6NRj) maintained under hypoxic conditions $\left(8 \% \mathrm{O}_{2}\right)$ for 24 hours, either untreated or treated with $\mathrm{CFTR}_{\mathrm{inh}}-172(1 \mathrm{mg} / \mathrm{kg}$ i.p. prior to hypoxia exposure). Under normoxic conditions, control mice and $\mathrm{CFTR}_{\text {inh }}$-172-treated mice (1 mg/kg i.p.) exhibited a similar hematocrit level (control, $50.2 \pm 0.8 \%$; CFTR $_{\text {inh }}-172,49.6 \pm 1.3 \%$ ) (Figure 7A). Exposing mice to $8 \% \mathrm{O}_{2}$ for 24 hours induced a large increase in hematocrit $(58.9 \pm 0.4 \%)$. This increase was significantly impaired in $\mathrm{CFTR}_{\text {inh }}$-172-treated mice $(56.0 \pm 0.5 \%)(P<$ $0.01)$. Because dehydration is one of the main cause of hematocrit increase (by a loss of plasma volume), we
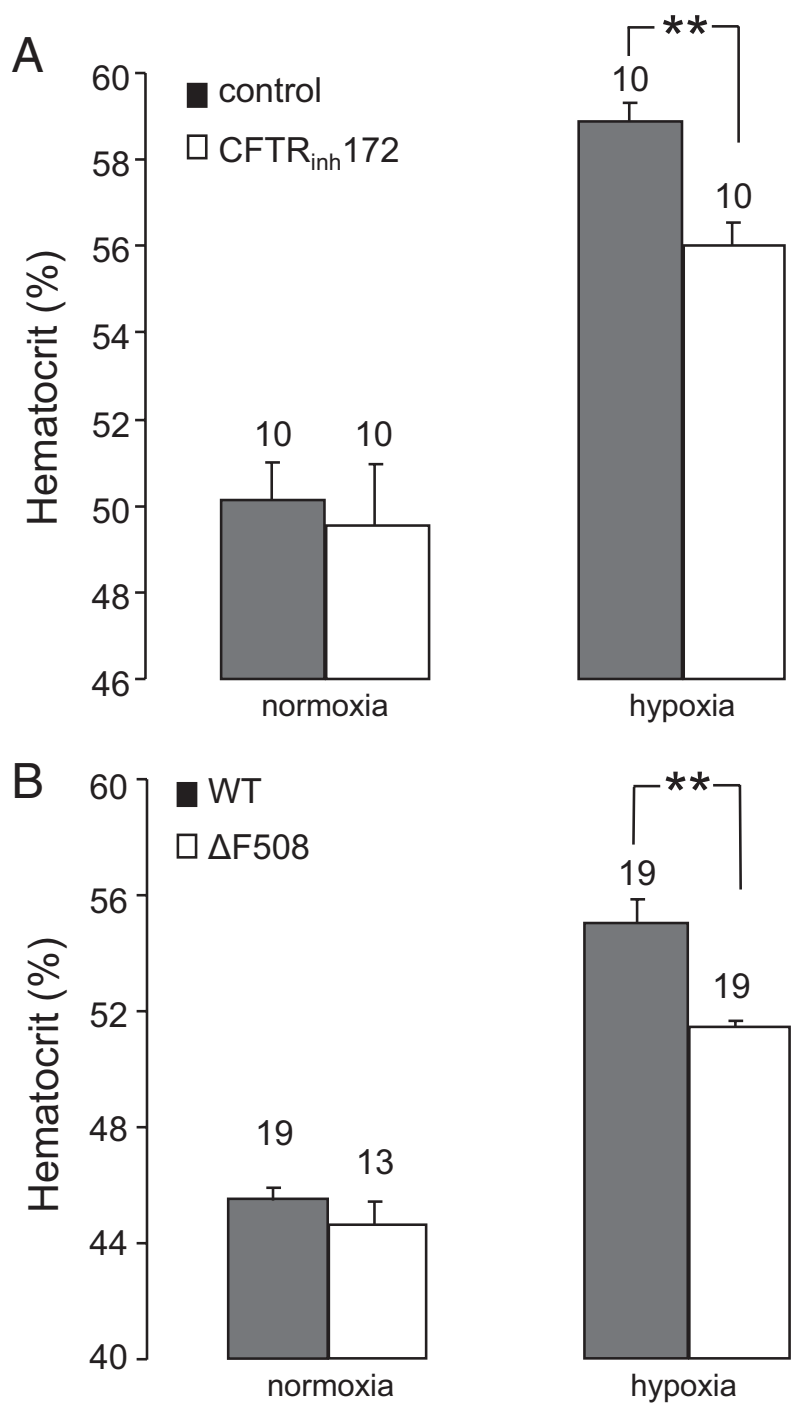

Figure 7. Effect of $\mathrm{CFTR}_{\mathrm{inh}}-172$ treatment and $\Delta \mathrm{F} 508$-CFTR mutation on the hematocrit percentage in mice exposed to hypoxia. A: WT C57BL/6NRj mice were maintained under normoxic $\left(20 \% \mathrm{O}_{2}\right)$ or hypoxic $\left(8 \% \mathrm{O}_{2}\right)$ conditions for 24 hours. At 1 hour before the beginning of the experiment, mice were injected intraperitoneally by vehicle alone (control) or with $\mathrm{CFTR}_{\mathrm{inh}}-172$ (1 $\mathrm{mg} / \mathrm{kg}$ ). At the end of the experiment, the blood of each animal was collected by retro-orbital withdrawal, and hematocrit was measured. B: WT (FVB strain) or $\Delta$ F508-CFTR mice were maintained under normoxic or hypoxic conditions for 24 hours (as in $\mathbf{A}$ ), and hematocrit was measured. Data are expressed as means \pm SEM of 10 mice (A) or 10, 13, or 19 mice (B) per experimental condition. ${ }^{*} P<0.01$ Student's $t$-test. 
Table 1. Urine Osmolarity in Untreated and $\mathrm{CFTR}_{\text {inh }}-172-$ Treated WT C57BL/6NRj Mice Exposed to Normoxia or Hypoxia

\begin{tabular}{|c|c|}
\hline Condition and genotype & Urine osmolarity (mOsm) \\
\hline Normoxia, control & $2050 \pm 101$ \\
\hline Normoxia, CFTR inh -172 -treated & $2370 \pm 232$ \\
\hline Hypoxia, control & $2130 \pm 214$ \\
\hline Hypoxia, CFTR inh-172-treated & $2113 \pm 171$ \\
\hline
\end{tabular}

Results are expressed as means \pm SEM of 10 mice in each experimental condition.

measured the osmotic pressure of the urine from hypoxic and normoxic mice either untreated or treated with CFTR $_{\text {inh }}$-172. The osmotic pressures of the urine in the four animal groups did not differ significantly, which excludes a putative hematocrit increase through possible dehydration (Table 1)

Finally, to validate the physiological relevance of CFTR in the control of the adaptive response to hypoxia in cystic fibrosis, in vivo experiments were performed using transgenic mice harboring the $\Delta \mathrm{F} 508$ mutation. Under normoxic conditions, WT mice (FVB background) and $\Delta$ F508 mice exhibited almost the same hematocrit level (WT, $45.5 \pm 0.4 \% ; \Delta$ F508, $44.6 \pm 0.8 \%$ ) (Figure 7B). Exposing WT mice to hypoxia $\left(8 \% \mathrm{O}_{2}\right)$ for 24 hours induced an increase in hematocrit that reached $54.9 \pm$ $0.2 \%(n=19)$. Remarkably, the $\Delta$ F508 mice exhibited a significantly lower hematocrit under hypoxic conditions $(51.40 \pm 0.2 \% ; P=0.01 ; n=19)$, compared with WT mice (Figure 7B), pointing to a crucial role of CFTR in the adaptive response to hypoxia. The osmotic pressures of the urine in the four animal groups were not significantly altered (Table 2)

\section{Inhibition of CFTR Impairs HIF1- $\alpha$ Stabilization in a Human Cell Model}

To determine the physiological relevance of our data, it remained to be established whether CFTR inhibition affects HIF1- $\alpha$ stabilization under hypoxia in a human CFTR-expressing cell model. First, using RT-PCR, we demonstrated that the HK-2 cells expressed CFTR (Figure $8 \mathrm{~A})$. We then exposed the HK-2 cells to hypoxia $\left(5 \% \mathrm{O}_{2}\right)$ for 24 hours in the presence or absence of $\mathrm{CFTR}_{\text {inh }}-172(5 \mu \mathrm{mol} / \mathrm{L})$ and analyzed HIF1- $\alpha$ expression by immunoblotting, normalized to $\beta$-actin (Figure $8, \mathrm{~B}$ and $\mathrm{C}$ ). As we had observed in the mouse cell model, hypoxia induced a huge increase in HIF1- $\alpha$

Table 2. Urine Osmolarity in WT and $\Delta$ F508-CFTR Mice Exposed to Normoxia or Hypoxia

\begin{tabular}{lc}
\hline Condition and genotype & Urine osmolarity $(\mathrm{mOsm})$ \\
\hline Normoxia, WT $(n=19)$ & $1598 \pm 227$ \\
Normoxia, $\Delta \mathrm{F}-508(n=13)$ & $1924 \pm 261$ \\
Hypoxia, control $(n=19)$ & $1228 \pm 94$ \\
Hypoxia, $\Delta \mathrm{F}-508(n=19)$ & $1424 \pm 89$ \\
\hline
\end{tabular}

Results are expressed as means \pm SEM of 13 or 19 mice in each experimental condition.
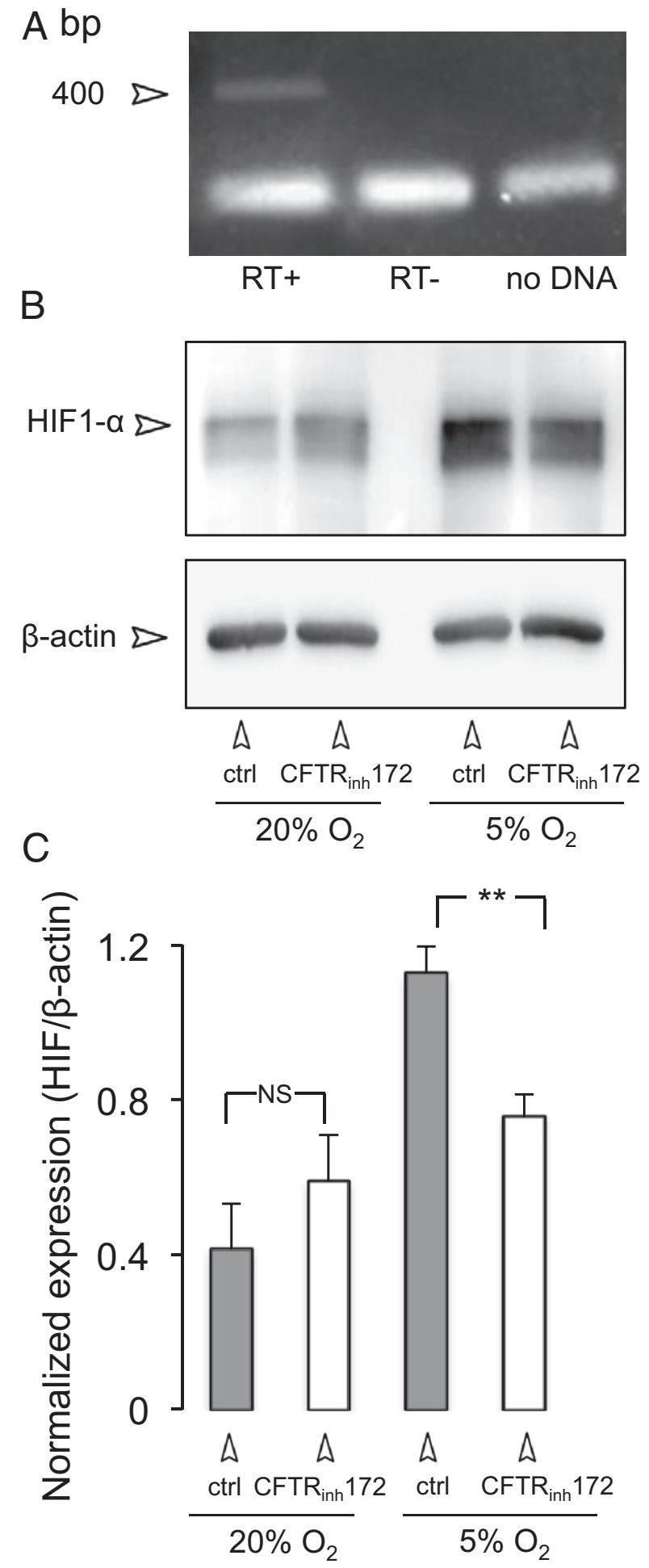

Figure 8. Effect of $\mathrm{CFTR}_{2}-172$ on HIF stabilization in HK-2 cells maintained under normoxic or hypoxic conditions for 24 hours. A: RT-PCR analysis of CFTR expression in HK-2 cell line. RT-PCR products using primers specific for human CFTR (between exons 5 and 8) generated a band of 401 bp (RT+). No amplification product was observed in the absence of reverse transcriptase (RT-) or in the absence of DNA (no DNA). B: Cell lysates from HK-2 cells exposed to normoxia $\left(20 \% \mathrm{O}_{2}\right)$ or hypoxia $\left(5 \% \mathrm{O}_{2}\right)$ for 24 hours were analyzed by SDSPAGE and immunoblotting to reveal HIF-1- $\alpha$ levels. The cells were cultured in the absence or presence of $\mathrm{CFTR}_{\mathrm{inh}^{-}}-172(5 \mu \mathrm{mol} / \mathrm{L})$. The blots were probed for $\beta$-actin, to monitor protein loading and transferring. C: The level of HIF-1- $\alpha$ was measured under normoxic and hypoxic conditions, in the absence or presence of $\mathrm{CFTR}_{\mathrm{inh}}-172(5 \mu \mathrm{mol} / \mathrm{L})$. For each experimental condition, the results were normalized to $\beta$-actin expression. Data are expressed as means \pm SEM of three independent Western blots. ${ }^{* *} P<0.01$ Student's $t$-test. 
stabilization, which was significantly inhibited in the presence of $\mathrm{CFTR}_{\text {inh }}-172$. These findings confirm the important role of CFTR in the hypoxia-mediated adaptive response in humans.

\section{Discussion}

One of the physiological effects associated with the impairment of lung function in cystic fibrosis disease is a hypoxic state that leads to anemia. ${ }^{4,5}$ In some cases, this anemic state is not compensated by the canonical physiological response linked to hypoxia, which increases the red blood cell mass to enhance tissue oxygen delivery. These observations raise the question of a possible link between the molecular mechanisms involved in the adaptive response to hypoxia and the functional expression of CFTR involved in the onset of cystic fibrosis.

To investigate a potential link between the functional expression of CFTR and the canonical HIF-mediated adaptive pathway, ${ }^{23}$ we used both in vitro and in vivo approaches to analyze the effect of CFTR inhibition in response to low oxygen levels. To inhibit CFTR, we used the pharmacological specific CFTR inhibitor $\mathrm{CFTR}_{\text {inh }}$ $172,{ }^{24}$ which has been used previously to mimic some phenotypic characteristics of CFTR-deficient mice, without deleterious effects. ${ }^{25}$ Another possibility would have been the use of $\mathrm{Cftr}^{-\prime-}$ knockout mice, but we decided against this in the present study because of unspecific modifications of the pattern of genes being expressed. ${ }^{26}$ Using a hypoxia cell reporter system based on the expression of the fusion protein ODD-GFP, ${ }^{17}$ we demonstrated that inhibition of CFTR clearly impaired HIF1- $\alpha$ stabilization under hypoxic conditions. Similar results were reported recently by Legendre et al. ${ }^{27}$

It was crucial to investigate any functional effect of CFTR inhibition on a target gene of oxygen deprivation. CA-IX is one of the most sensitive endogenous sensors of HIF-1 activity, ${ }^{22}$ because of the unique structure of its promoter. CA-IX was strongly expressed under hypoxia in PCT cells. Specific CFTR inhibition during hypoxia led to a dramatic decrease in CA-IX expression. Interestingly, addition of the ROS scavenger NAC also drastically impaired CA-IX expression. Even if ROS generation during hypoxia is still controversial, ${ }^{28}$ some studies using DCFDA probe and fluorescence resonance energy transfer have demonstrated an increase in total intracellular ROS on hypoxia. ${ }^{29,30}$ Our data confirm that, in PCTs, hypoxia induces an increase in intracellular ROS that is prevented by CFTR inhibition. It has also been shown by others that ROS could act as signaling agents in diverse functional responses, including activation of gene expression through the stabilization of the transcription factor HIF1- $\alpha .{ }^{31,32}$ Our result suggests a close correlation between oxidative stress and CFTR activity. The molecular mechanism involved in the intracellular ROS level controlled by CFTR remains to be identified.

In addition to the canonical permeability of CFTR to $\mathrm{Cl}^{-}$, various studies have shown that CFTR can mediate the transport of reduced $\mathrm{GSH} .{ }^{18,33}$ We have already demonstrated that CFTR is able to modulate the intracel- lular ROS level in staurosporine-induced apoptosis ${ }^{19}$ and in cadmium-induced cell death. ${ }^{12}$ This control is probably mediated through the ability of CFTR to transport GSH outside cells. ${ }^{34}$ The important role of CFTR in relation to GSH has also been demonstrated by Gould et al, ${ }^{20}$ in the cigarette smoke-induced adaptive response, and by Jungas et al, ${ }^{35}$ who found that GSH-dependent BAX activation in cells with normal CFTR represents an early step in oxidative stress-induced apoptosis. Because GSH is the main physiological ROS scavenger in proximal cells, and because the stabilization of HIF1 is dependent on the cell redox status, ${ }^{36}$ one could assume that the fine regulation of GSH concentration by CFTR plays a crucial role in the signaling pathway leading to HIF stabilization.

Exposure of proximal cells to hypoxia activates a $\mathrm{Cl}^{-}$ current that shares the biophysical properties of the CFTR $\mathrm{Cl}^{-}$current. On the other hand, it has been demonstrated in the intestinal epithelium that CFTR expression can be transcriptionally repressed after exposure to hypoxia. ${ }^{37}$ Another study identified a repressive effect of hypoxia on CFTR expression in HT29 and Calu-3 cells. ${ }^{38}$ These data are not in conflict with ours, because those authors did not take into consideration the initial period $(<24$ hours) during which the early adaptive response takes place. It is likely that a long exposure to hypoxia (from 24 hours to 3 days) induces a fall in the ATP level in cells, ${ }^{39}$ leading most probably to a massive repression of the translational machinery, including CFTR translation. The mechanism by which CFTR is activated during hypoxia remains to be determined, but we can exclude a direct effect of CAMP, because our data demonstrate clearly that HIF1- $\alpha$ stabilization is not dependent on CAMP-mediated CFTR activation alone. It has already been reported that $\mathrm{H}_{2} \mathrm{O}_{2}$ is able to activate CFTR through cyclooxygenase- and mPGES-1-dependent release of

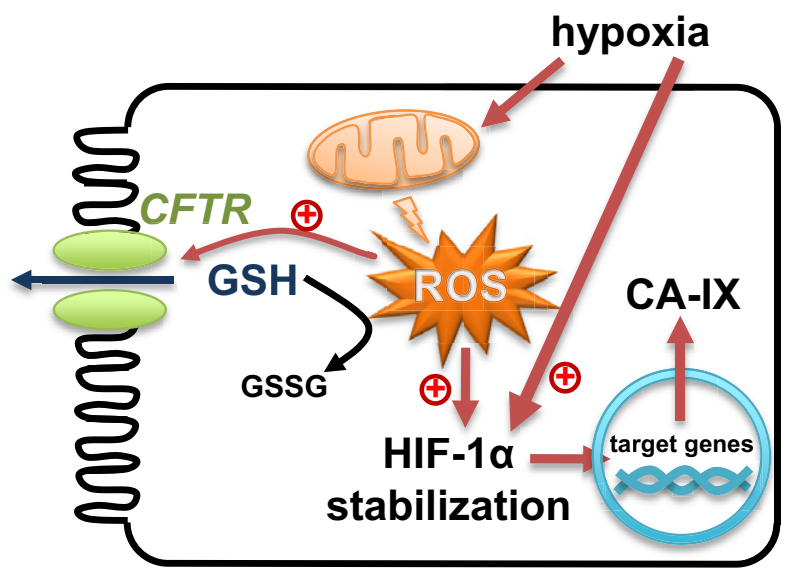

Figure 9. Schematic representation of the role of CFTR in the hypoxiainduced adaptive response in renal cell. Hypoxia inhibits proteasomal degradation of the HIF-1- $\alpha$ that accumulates in the cytosol. Simultaneously, hypoxia induces production of ROS (which play a helper role in HIF1- $\alpha$ stabilization) from mitochondria. ROS activates CFTR, allowing GSH to flow out of the cell. A dysfunction of CFTR (CFTR inh -172 or $\Delta \mathrm{F} 508$ mutation) enhances the cell content of GSH, which scavenges ROS. Thus, the cell redox status depends on a fine equilibrium between ROS production and the natural ROS scavenger GSH. This fine regulation of the redox status modulated by CFTR affects HIF stabilization and the target genes involved in the hypoxic adaptive response, such as the CA-IX gene. 
PGE2. ${ }^{40}$ Thus, our hypothesis is that the ROS increase triggered by hypoxia in our experimental conditions activates CFTR.

To further confirm the importance of CFTR in the physiological response to oxygen deprivation, we performed two sets of experiments using CFTR $_{\text {inh }}$-172-treated mice and a $\triangle$ F508-CFTR mouse model. For both models, we chose to expose mice to hypoxia for 24 hours, a time period sufficient to induce a significant increase in hematocrit under hypoxic conditions. ${ }^{41}$ The hematocrit measurements clearly indicated that treatment with the CFTR inhibitor significantly impaired the red blood cell mass increase induced by hypoxia. Previous studies of the in vivo effect of $\mathrm{CFTR}_{\text {inh }}-172$ have demonstrated its physiological relevance. First, CFTR inh $^{-172}$ has low renal toxicity, low renal excretion, and is not metabolized. ${ }^{42}$ Second, a single intraperitoneal injection of CFTR inh $^{-172}$ significantly reduced cholera toxin-induced intestinal fluid loss for several hours. ${ }^{24}$ Similar to the CFTR inh -172 mouse model, use of the $\Delta$ F508 mice model showed that the hypoxia-induced hematocrit rise was impaired, confirming the crucial role of CFTR in the adaptation to hypoxia.

In cystic fibrosis disease, the relevant concern is mainly the $\Delta F 508$ mutation of CFTR, which remains partially active. ${ }^{43,44}$ An argument supporting our hypothesis on the role of CFTR in ROS control is that, in cystic fibrosis patients, the fluid lining the lung epithelium contains a reduced level of GSH, compared with that of healthy subjects. It was suggested that such a reduced level is related to a GSH transport reduction. ${ }^{45}$ Despite these data, Wetmore et al ${ }^{46}$ demonstrated, in primary cultures of airway epithelial cells from cystic fibrosis patients, that the GSH content is lower than in cells from healthy patients. Thus, whether lung epithelial GSH is reduced in cystic fibrosis is still under debate, and the differences could be attributed to the different models used. Our data support the hypothesis that in these epithelial cells the ROS buffering capacity is disturbed, potentially leading to defects in the intracellular ROS signaling pathway. We present a schematic summary of the role of CFTR in control of cell redox through its capacity to transport GSH out of the cell (Figure 9).

In conclusion, using both in vivo and in vitro approaches, we have demonstrated that CFTR is involved in the HIF1- $\alpha$-mediated early adaptive response to hypoxia, and that such modulation is mediated through a control of CFTR on the intracellular ROS level, which could act as a helper signaling agent in the HIF1- $\alpha$ stabilization process. This control could be relevant in cystic fibrosis disease, explaining the noncompensated anemic condition in cystic fibrosis patients.

\section{Acknowledgments}

We thank Dr. Gisela d'Angelo for the gift of the ODD-GFPcontaining plasmid and Dr. Eric Rondeau for the gift of the HK-2 cell line.

\section{References}

1. Fuller CM, Benos DJ. CFTR!. Am J Physiol 1992, 263:C267-86

2. Tsui LC. The cystic fibrosis transmembrane conductance regulator gene. Am J Respir Crit Care Med 1995, 151:S47-53

3. Zemanick ET, Harris JK, Conway S, Konstan MW, Marshall B, Quittner AL, Retsch-Bogart G, Saiman L, Accurso FJ. Measuring and improving respiratory outcomes in cystic fibrosis lung disease: opportunities and challenges to therapy. J Cyst Fibros 2010, 9:1-16

4. O'Connor TM, McGrath DS, Short C, O'Donnell MJ, Sheehy M, Bredin CP: Subclinical anaemia of chronic disease in adult patients with cystic fibrosis. J Cyst Fibros 2002, 1:31-34

5. Fischer R, Simmerlein R, Huber RM, Schiffl H, Lang SM: Lung disease severity, chronic inflammation, iron deficiency, and erythropoietin response in adults with cystic fibrosis. Pediatr Pulmonol 2007, 42: 1193-1197

6. Dunn A, Lo V, Donnelly S: The role of the kidney in blood volume regulation: the kidney as a regulator of the hematocrit. Am J Med Sci 2007, 334:65-71

7. Barrière H, Belfodil R, Rubera I, Tauc M, Poujeol C, Bidet M, Poujeol $P$ : CFTR null mutation altered CAMP-sensitive and swelling-activated $\mathrm{Cl}$ - currents in primary cultures of mouse nephron. Am J Physiol Renal Physiol 2003, 284:F796-F811

8. Nakayama K: Cellular signal transduction of the hypoxia response. J Biochem 2009, 146:757-765

9. Kuijper A, van der Groep P, van der Wall E, van Diest PJ: Expression of hypoxia-inducible factor 1 alpha and its downstream targets in fibroepithelial tumors of the breast. Breast Cancer Res 2005, 7:R808R818

10. Nangaku M, Eckardt KU: Hypoxia and the HIF system in kidney disease. J Mol Med (Berl) 2007, 85:1325-1330

11. L'Hoste S, Poet M, Duranton C, Belfodil R, é Barriere H, Rubera I, Tauc M, Poujeol C, Barhanin J, Poujeol P: Role of TASK2 in the control of apoptotic volume decrease in proximal kidney cells. J Biol Chem 2007, 282:36692-36703

12. L'Hoste S, Chargui A, Belfodil R, Duranton C, Rubera I, Mograbi B, Poujeol C, Tauc M, Poujeol P: CFTR mediates cadmium-induced apoptosis through modulation of ROS level in mouse proximal tubule cells. Free Radic Biol Med 2009, 46:1017-1031

13. Wang YF, Shyu HW, Chang YC, Tseng WC, Huang YL, Lin KH, Chou MC, Liu HL, Chen CY: Nickel (II)-induced cytotoxicity and apoptosis in human proximal tubule cells through a ROS- and mitochondriamediated pathway. Toxicol Appl Pharmacol 2012, 259:177-186

14. Chargui A, Zekri S, Jacquillet G, Rubera I, llie M, Belaid A, Duranton C, Tauc M, Hofman P, Poujeol P, El May MV, Mograbi B: Cadmiuminduced autophagy in rat kidney: an early biomarker of subtoxic exposure. Toxicol Sci 2011, 121:31-42

15. Ivan M, Kondo K, Yang H, Kim W, Valiando J, Ohh M, Salic A, Asara JM, Lane WS, Kaelin WG Jr: HIFalpha targeted for VHL-mediated destruction by proline hydroxylation: implications for $\mathrm{O} 2$ sensing, Science 2001, 292:464-468

16. Jaakkola P, Mole DR, Tian YM, Wilson MI, Gielbert J, Gaskell SJ, Kriegsheim A, Hebestreit HF, Mukherji M, Schofield CJ, Maxwell PH, Pugh CW, Ratcliffe PJ: Targeting of HIF-alpha to the von HippelLindau ubiquitylation complex by O2-regulated prolyl hydroxylation. Science 2001, 292:468-472

17. D'Angelo G, Duplan E, Boyer N, Vigne P, Frelin C: Hypoxia upregulates prolyl hydroxylase activity: a feedback mechanism that limits HIF-1 responses during reoxygenation. J Biol Chem 2003, 278:38183-38187

18. Kogan I, Ramjeesingh M, Li C, Kidd JF, Wang Y, Leslie EM, Cole SP, Bear CE: CFTR directly mediates nucleotide-regulated glutathione flux. EMBO J 2003, 22:1981-1989

19. L'Hoste S, Chargui A, Belfodil R, Corcelle E, Duranton C, Rubera I, Poujeol C, Mograbi B, Tauc M, Poujeol P: CFTR mediates apoptotic volume decrease and cell death by controlling glutathione efflux and ROS production in cultured mice proximal tubules. Am J Physiol Renal Physiol 2010, 298:F435-F453

20. Gould NS, Min E, Martin RJ, Day BJ: CFTR is the primary known apical glutathione transporter involved in cigarette smoke-induced adaptive responses in the lung. Free Radic Biol Med 2012, 52:12011206 
21. Santamaria G, Martínez-Diez M, Fabregat I, Cuezva JM: Efficient execution of cell death in non-glycolytic cells requires the generation of ROS controlled by the activity of mitochondrial H+-ATP synthase. Carcinogenesis 2006, 27:925-935

22. Kaluz S, Kaluzová M, Liao SY, Lerman M, Stanbridge EJ: Transcriptional control of the tumor- and hypoxia-marker carbonic anhydrase 9: a one transcription factor (HIF-1) show? Biochim Biophys Acta 2009, 1795:162-172

23. Webb JD, Coleman ML, Pugh CW: Hypoxia, hypoxia-inducible factors (HIF). HIF hydroxylases and oxygen sensing. Cell Mol Life Sci 2009, 66:3539-3554

24. Ma T, Thiagarajah JR, Yang H, Sonawane ND, Folli C, Galietta LJ, Verkman AS: Thiazolidinone CFTR inhibitor identified by highthroughput screening blocks cholera toxin-induced intestinal fluid secretion. J Clin Invest 2002, 110:1651-1658

25. Perez A, Issler AC, Cotton CU, Kelley TJ, Verkman AS, Davis PB CFTR inhibition mimics the cystic fibrosis inflammatory profile. Am J Physiol Lung Cell Mol Physiol 2007, 292:L383-L395

26. Guilbault C, Novak JP, Martin P, Boghdady ML, Saeed Z, Guiot MC Hudson TJ, Radzioch D: Distinct pattern of lung gene expression in the Cftr-KO mice developing spontaneous lung disease compared with their littermate controls. Physiol Genomics 2006, 25:179-193

27. Legendre C, Mooij MJ, Adams C, O'Gara F: Impaired expression of hypoxia-inducible factor-1alpha in cystic fibrosis airway epithelia cells-A role for HIF-1 in the pathophysiology of CF? J Cyst Fibros 2011, 10:286-290

28. Cash TP, Pan Y, Simon MC: Reactive oxygen species and cellular oxygen sensing. Free Radic Biol Med 2007, 43:1219-1225

29. Mansfield KD, Guzy RD, Pan Y, Young RM, Cash TP, Schumacker PT Simon MC: Mitochondrial dysfunction resulting from loss of cytochrome c impairs cellular oxygen sensing and hypoxic HIF-alpha activation. Cell Metab 2005, 1:393-399

30. Poyton RO, Ball KA, Castello PR: Mitochondrial generation of free radicals and hypoxic signaling. Trends Endocrinol Metab 2009, 20 : 332-340

31. Guzy RD, Schumacker PT: Oxygen sensing by mitochondria at complex III: the paradox of increased reactive oxygen species during hypoxia. Exp Physiol 2006, 91:807-819

32. Sasabe E, Yang Z, Ohno S, Yamamoto T: Reactive oxygen species produced by the knockdown of manganese-superoxide dismutase up-regulate hypoxia-inducible factor-1alpha expression in oral squamous cell carcinoma cells. Free Radic Biol Med 2010, 48:1321-1329

33. Linsdell P, Hanrahan JW: Glutathione permeability of CFTR. Am J Physiol 1998, 275:C323-C326

34. Childers M, Eckel G, Himmel A, Caldwell J: A new model of cystic fibrosis pathology: lack of transport of glutathione and its thiocyanate conjugates. Med Hypotheses 2007, 68:101-112

35. Jungas T, Motta I, Duffieux F, Fanen P, Stoven V, Ojcius DM: Glutathione levels and BAX activation during apoptosis due to oxidative stress in cells expressing wild-type and mutant cystic fibrosis transmembrane conductance regulator. J Biol Chem 2002, 277:27912-27918

36. Tajima M, Kurashima Y, Sugiyama K, Ogura T, Sakagami H: The redox state of glutathione regulates the hypoxic induction of HIF-1. Eur J Pharmacol 2009, 606:45-49

37. Zheng W, Kuhlicke J, Jäckel K, Eltzschig HK, Singh A, Sjöblom M, Riederer B, Weinhold C, Seidler U, Colgan SP, Karhausen J: Hypoxia inducible factor-1 (HIF-1)-mediated repression of cystic fibrosis transmembrane conductance regulator (CFTR) in the intestinal epithelium. FASEB J 2009, 23:204-213

38. Guimbellot JS, Fortenberry JA, Siegal GP, Moore B, Wen H, Venglarik C, Chen YF, Oparil S, Sorscher EJ, Hong JS: Role of oxygen availability in CFTR expression and function. Am J Respir Cell Mol Biol 2008, 39:514-521

39. Hayashi K, Ochiai T, Ishinoda Y, Okamoto T, Maruyama T, Tsuda K, Tsubouchi H: Relationship between cellular ATP content and cellular functions of primary cultured rat hepatocytes in hypoxia [Erratum appeared in J Gastroenterol Hepatol 1997, 12:620]. J Gastroenterol Hepatol 1997, 12:249-256

40. Soodvilai S, Jia Z, Yang T: Hydrogen peroxide stimulates chloride secretion in primary inner medullary collecting duct cells via mPGES1-derived PGE2. Am J Physiol Renal Physiol 2007, 293:F1571-F1576

41. Zelko IN, Folz RJ: Extracellular superoxide dismutase functions as a major repressor of hypoxia-induced erythropoietin gene expression. Endocrinology 2005, 146:332-340

42. Sonawane ND, Muanprasat C, Nagatani R Jr, Song Y, Verkman AS: In vivo pharmacology and antidiarrheal efficacy of a thiazolidinone CFTR inhibitor in rodents. J Pharm Sci 2005, 94:134-143

43. Ostedgaard LS, Meyerholz DK, Chen JH, Pezzulo AA, Karp PH, Rokhlina T, Ernst SE, Hanfland RA, Reznikov LR, Ludwig PS, Rogan MP, Davis GJ, Dohrn CL, Wohlford-Lenane C, Taft PJ, Rector MV, Hornick E, Nassar BS, Samuel M, Zhang Y, Richter SS, Uc A, Shilyansky J, Prather RS, McCray PB Jr, Zabner J, Welsh MJ, Stoltz DA: The DeltaF508 mutation causes CFTR misprocessing and cystic fibrosis-like disease in pigs. Sci Transl Med 2011, 74ra243:

44. van Barneveld A, Stanke F, Tamm S, Siebert B, Brandes G, Derichs $\mathrm{N}$, Ballmann M, Junge S, Tümmler B: Functional analysis of F508del CFTR in native human colon. Biochim Biophys Acta 2010, 1802 : 1062-1069

45. Gao L, Kim KJ, Yankaskas JR, Forman HJ: Abnormal glutathione transport in cystic fibrosis airway epithelia. Am J Physiol 1999, 277: L113-L118

46. Wetmore DR, Joseloff E, Pilewski J, Lee DP, Lawton KA, Mitchell MW, Milburn MV, Ryals JA, Guo L: Metabolomic profiling reveals biochemical pathways and biomarkers associated with pathogenesis in cystic fibrosis cells. J Biol Chem 2010, 285:30516-30522 